\title{
Establishing Molecular Methods to Quantitatively Profile Gastric Diet Items of Fish-Application to the Invasive Blue Catfish (Ictalurus furcatus)
}

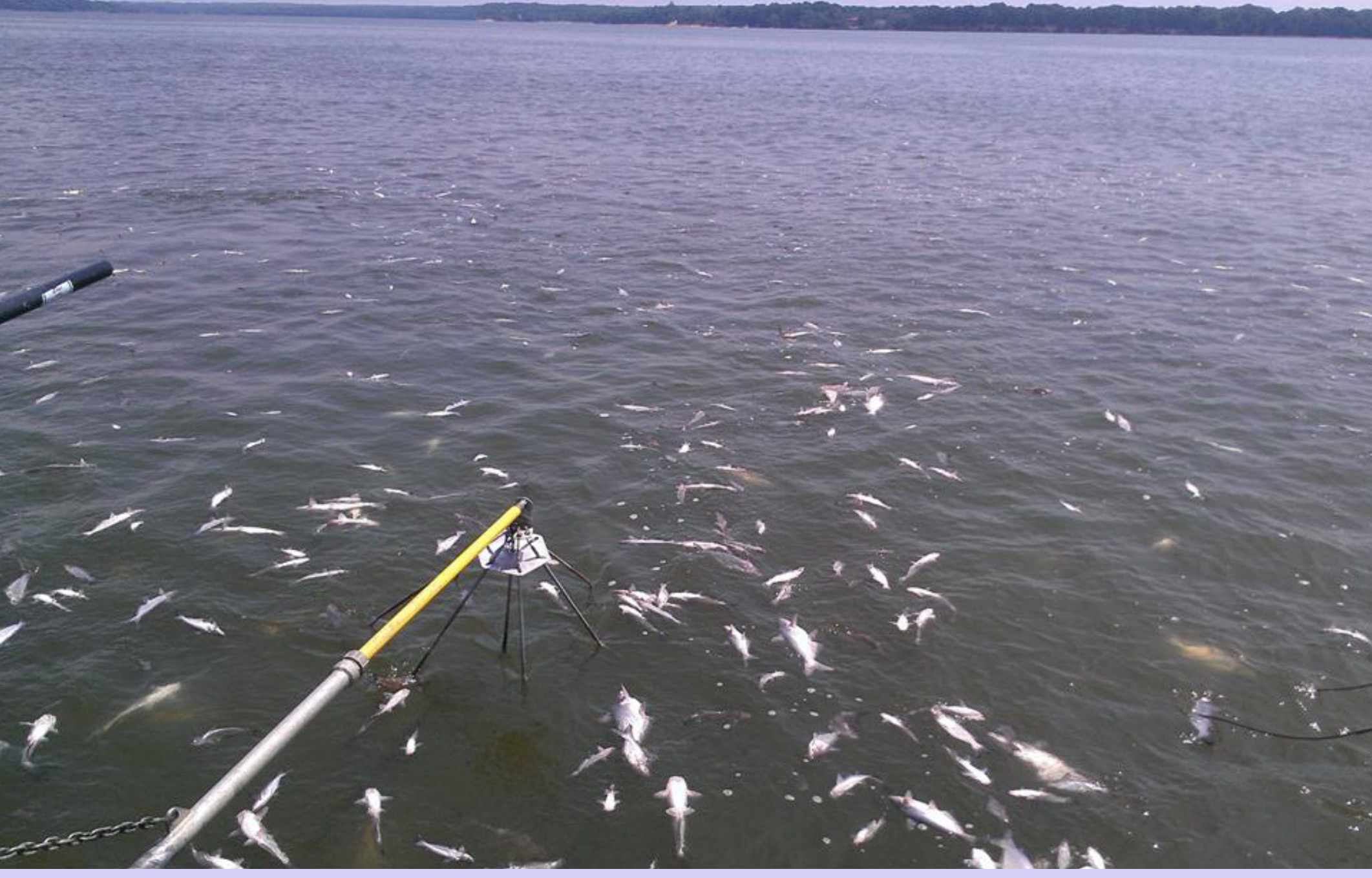

Open-File Report 2019-1021 
Cover. Photo of result of low-frequency electrofishing on the tidal Potomac River near Washington D.C. This photograph was taken using a GoPro camera mounted on a 20 foot staff, photograph by Maryland Department of Natural Resources, Fisheries Service. 


\section{Establishing Molecular Methods to Quantitatively Profile Gastric Diet Items of Fish-Application to the Invasive Blue Catfish (Ictalurus furcatus)}

By Deborah D. Iwanowicz, William B. Schill, Lakyn R. Sanders, Tim Groves, and Mary C. Groves

Open-File Report 2019-1021 


\title{
U.S. Department of the Interior \\ DAVID BERNHARDT, Acting Secretary
}

\author{
U.S. Geological Survey \\ James F. Reilly II, Director
}

U.S. Geological Survey, Reston, Virginia: 2019

For more information on the USGS - the Federal source for science about the Earth, its natural and living resources, natural hazards, and the environment-visit https://www.usgs.gov or call 1-888-ASK-USGS.

For an overview of USGS information products, including maps, imagery, and publications,

visit https://store.usgs.gov.

Any use of trade, firm, or product names is for descriptive purposes only and does not imply endorsement by the U.S. Government.

Although this information product, for the most part, is in the public domain, it also may contain copyrighted materials as noted in the text. Permission to reproduce copyrighted items must be secured from the copyright owner.

Suggested citation:

Iwanowicz, D.D., Schill, W.B., Sanders, L.R., Groves, T., and Groves, M.C., 2019, Establishing molecular methods to quantitatively profile gastric diet items of fish-Application to the invasive blue catfish (/ctalurus furcatus): U.S. Geological Survey Open-File Report 2019-1021, 15 p., https://doi.org/10.3133/ofr20191021.

ISSN 2331-1258 (online) 


\section{Acknowledgments}

The authors would like to thank John Young for his creation of the map and the Maryland

Department of Natural Resources (MD DNR) for collecting all fish samples. Fish collections, protocols, and permits were authorized by the MD DNR. 



\section{Contents}

Abstract

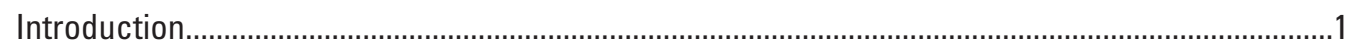

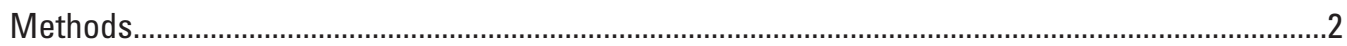

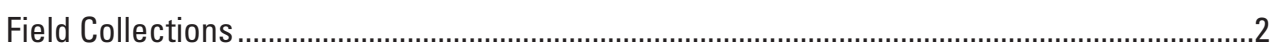

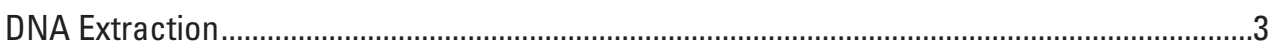

Targeted Amplification of Mitochondrial Regions...................................................................

Generation of Mock Library Samples..................................................................................

Sequencing Library Preparation and Quality Assessment.......................................................

Read Filtering, Trimming, and RNAseq Metabarcoding Assembly..........................................

Reference Database and Taxonomic Analysis ......................................................................

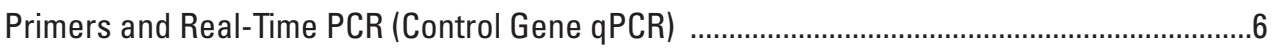

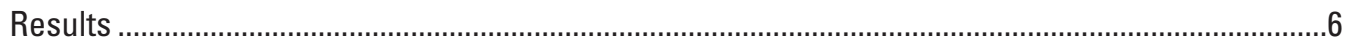

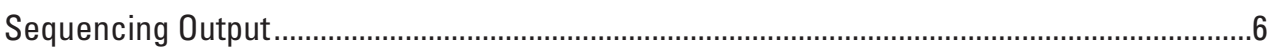

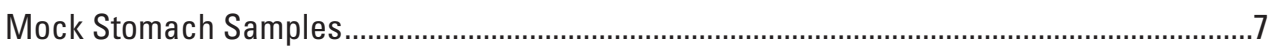

Blue Catfish Stomach Samples ..........................................................................................

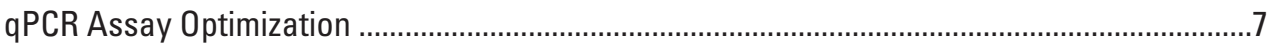

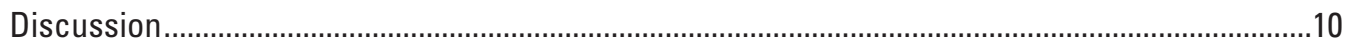

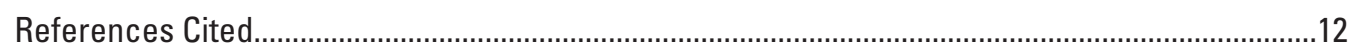

Appendix 1. Species with Accession Number and Sequence ..................................................15

Available online as PDF file at https://doi.org/10.3133/ofr20191021 


\section{Figures}

1. Map showing three sites where Ictalurus furcatus (blue catfish) were collected from major tributaries of the Potomac River.

2. Graphs showing average proportion of mapped reads and number of stomach samples in which prey species were detected in Ictalurus furcatus (blue catfish) with the mt12S primer set, by recovered $A$, fish species and $B$, fish genera.

3. Graphs showing average proportion of mapped reads and number of stomach samples in which prey species were detected in Ictalurus furcatus (blue catfish) with the mt16S primer set, by recovered $A$, fish species and $B$, fish genera.

4. Graph showing threshold values in relation to counts generated by assaying fish samples with the Perca flavescens (yellow perch) real-time polymerase chain reaction assay.

\section{Tables}

1. Length, weight, and collection date for 12 Ictalurus furcatus collected from the site at either Mattawoman Creek or Nanjemoy Creek in Maryland.

2. Data on seven field-collected fish species archived at the laboratory and used for the mock library

3. Fish species whose genomic DNA was used to verify the specificity of the real-time polymerase chain reaction for Perca flavescens.

4. Seven fish species included in mock samples along with the percent contribution they were found in the DNA assemblage

5. Concentration of primers and probe used for the detection of Perca flavescens (yellow perch) in real-time polymerase chain reaction assay 


\section{Conversion Factors}

\begin{tabular}{|c|c|c|}
\hline Multiply & By & To obtain \\
\hline \multicolumn{3}{|c|}{ Length } \\
\hline millimeter (mm) & 0.03937 & inch (in.) \\
\hline \multicolumn{3}{|c|}{ Volume } \\
\hline liter (L) & 33.81402 & ounce, fluid (fl. oz) \\
\hline liter $(\mathrm{L})$ & 2.113 & $\operatorname{pint}(\mathrm{pt})$ \\
\hline liter (L) & 1.057 & quart (qt) \\
\hline liter (L) & 0.2642 & gallon (gal) \\
\hline \multicolumn{3}{|c|}{ Mass } \\
\hline $\operatorname{gram}(\mathrm{g})$ & 0.03527 & acre-foot per day (acre-ft/d) \\
\hline
\end{tabular}

Temperature in degrees Celsius $\left({ }^{\circ} \mathrm{C}\right)$ may be converted to degrees Fahrenheit $\left({ }^{\circ} \mathrm{F}\right)$ as follows:

$$
{ }^{\circ} \mathrm{F}=\left(1.8 \times{ }^{\circ} \mathrm{C}\right)+32 .
$$

Temperature in degrees Fahrenheit $\left({ }^{\circ} \mathrm{F}\right)$ may be converted to degrees Celsius $\left({ }^{\circ} \mathrm{C}\right)$ as follows:

$$
{ }^{\circ} \mathrm{C}=\left({ }^{\circ} \mathrm{F}-32\right) / 1.8 \text {. }
$$

\section{Abbreviations}

$\begin{array}{ll}\text { A } & \text { adenine } \\ \text { BLAST } & \text { Basic Local Alignment Sequence Tool } \\ \text { bp } & \text { base pairs } \\ \text { C } & \text { cytosine } \\ \text { COX1 } & \text { cytochrome c oxidase 1 } \\ \text { G } & \text { guanine } \\ \text { MD DNR } & \text { Maryland Department of Natural Resources } \\ \text { mt } & \text { mitochondrial } \\ \text { NCBI } & \text { National Center for Biotechnology Information } \\ \text { PBS } & \text { phosphate-buffered saline } \\ \text { PCR } & \text { polymerase chain reaction } \\ \text { T } & \text { thymine } \\ \text { USGS } & \text { U.S. Geological Survey }\end{array}$





\title{
Establishing Molecular Methods to Quantitatively Profile Gastric Diet Items of Fish-Application to the Invasive Blue Catfish (Ictalurus furcatus)
}

\author{
By Deborah D. Iwanowicz', William B. Schill', Lakyn R. Sanders², Tim Groves³, and Mary C. Groves ${ }^{3}$
}

\section{Abstract}

Understanding the diet of invasive species helps researchers to more accurately assess the health, survivorship, growth, and stability of an invasive fish species, as well as their effects on native populations. Techniques capable of identifying multiple prey species from fish stomach contents have been developed. In this study, a multi-locus metabarcoding approach was used to identify fish and invertebrate prey in stomach samples of Ictalurus furcatus (blue catfish), which were collected from two sites on the Mattawomen Creek and Nanjemoy Creek in Maryland.

The mitochondrial $12 \mathrm{~S}(\mathrm{mt} 12 \mathrm{~S})$ and mitochondrial $16 \mathrm{~S}$ (mt16S) gene regions were sequenced and compared. First, a mock sample for each gene region was created with the pooled polymerase chain reaction product of known fish species, and quantities of the sample were used to determine efficacy of the amplicon. Results varied between gene regions analyzed. Then, when using the mt12S primers, next-generation sequencing determined that nine fish species were found at levels greater than 1 percent of the diet of blue catfish. The most common species were Perca flavescens (yellow perch) and Cyprinus carpio (common carp). The mt $16 \mathrm{~S}$ gene region analyses found 10 fish species at greater than 1 percent of the diet, which primarily included Orconectes limosus (spinycheek crayfish), Alosa pseudoharengus (alewife), and yellow perch. Partially digested eggs were identified using next-generation sequencing of yellow perch in two of the stomach samples, and a TaqMan ${ }^{\circledR}$ quantitative polymerase chain reaction (qPCR) assay was developed to more economically identify egg species in the future.

The yellow-perch-specific TaqMan ${ }^{\circledR}$ qPCR assay was tested using primers that were developed to detect a 154-basepair amplicon in the mitochondrial control region. Consumption of yellow perch eggs indicates that blue catfish could

${ }^{1}$ U.S. Geological Survey, National Fish Health Research Laboratory.

${ }^{2}$ Natural Systems Analyst, Inc., contracted to the U.S. Geological Survey, National Fish Health Research Laboratory.

${ }^{3}$ Maryland Department of Natural Resources, Inland Fisheries, Cedarville Fish Hatchery. potentially negatively affect young-of-year recruitment of this native sportfish. Analyses of two gene regions helped confirm the major prey of the fish sampled and allowed identification of fish species as prey that were not included in a database for the two gene regions. We concluded that the mitochondrial ribosomal-marker-based next-generation sequencing method is useful in determining the prey of fish species.

\section{Introduction}

Ictalurus furcatus (blue catfish) is the largest of the freshwater catfish species in the United States and is native to the Mississippi, Missouri, and Ohio River Basins (Graham 1999). Although the blue catfish primarily inhabits freshwater, they are known to tolerate and occupy estuarine habitats (Perry, 1969). During the last 50 years (1969-2018), blue catfish have been stocked across the United States (Graham, 1999) because of their value to sport and commercial fisheries (Michaeletz and Dillard, 1999). The popularity of blue catfish in the Midwest prompted stocking and introductions of these fish outside of their native range (Schloesser et al., 2011). Blue catfish were introduced into the James, Rappahannock, and York Rivers in Virginia during the 1970s. Subsequently, they have been observed in several rivers and tributaries in Maryland and the Chesapeake Bay from near the coast to the mouth of the Susquehanna River (Schloesser and others, 2011). They also have been reported in the Virginia Chesapeake Bay drainages in 1974 and the Potomac River in Maryland between 1898 and 1905 (Graham, 1999). This species has become established in some rivers in Virginia and is rapidly expanding its range. There is concern that this expansion increases the potential for the blue catfish to negatively affect native species and their complex ecological roles in the Chesapeake Bay (Schloesser and others, 2011). Invasive species are known to negatively affect established fish populations where they have been introduced. This occurs through competition with native species for food sources, predation, and habitat alteration (Sakai and others, 2001). Introduced blue catfish populations are suspected of adversely affecting native fish assemblages (Tuckey and Fabrizio, 2010). The increase of predatory invasive species, such as blue catfish, in the Chesapeake Bay and its tributaries 
could have an effect on the ecology of estuarine (Schloesser and others, 2011) and freshwater communities. Blue catfish are opportunistic omnivores that eat plant matter, insects, crustaceans, worms, and other fishes. Growing numbers and rapid expansion of blue catfish in the Chesapeake Bay have raised concerns about their potential negative effects on Brevoortia tyrannus (menhaden), Callinectes sapidus (blue crab), and other native species that play an important role in the ecosystem and economy (Schloesser and others, 2011; Garman and others, 2013).

The overall effect of an invasive species on an ecosystem is complex to quantify (Pimentel and others, 2005). Invasive species may affect not only an ecosystem's trophic structure, but also the region's socioeconomic assets (JanuchowskiHartley and others, 2017), although not all the effects are necessarily negative. For instance, an aquatic invasive species may precipitate a decline or extirpation of a native species or decline of ecosystem services but may also add value to a region's sport fishery (Pimentel and others, 2005; Schloesser and others, 2011).

The potential effect of blue catfish on fishery resources is of significant interest to fisheries managers along the Atlantic coast. In 2012, fisheries managers from the State of Maryland, Commonwealth of Virginia, District of Columbia, Potomac River Fisheries Commission, and Atlantic States Marine Fisheries Commission adopted an invasive catfish policy (Chesapeake Bay Program, 2012). This policy states that the potential risk posed by blue catfish on native species warrants action to examine potential measures to reduce densities and limit range expansion, as well as the need to evaluate potential negative ecological effects. Specifically, there was an interest in improving the understanding of the blue catfish biology and population dynamics. One way to determine the biological effect of an invasive species is through its diet.

Diet is an important factor underlying health, and survivorship, population growth, and stability among fishes. Diet analysis can provide crucial information for monitoring and restoration efforts for rare and endangered species, track consumption of native fishes by invasive species, and monitor changes in available prey of important sport fisheries. One of the most common methods for determining the diet of species of interest is macroscopic or microscopic examination. Although these methods provide beneficial information, there are limiting factors, such as labor, expert knowledge, time, and cost (Iwanowicz and others, 2016). Often, we find that microscopy can underestimate prey species consumed because of differences in digestibility or decomposition rates (Barker, 1986). Recent studies have used multiple DNA strategies that allow high taxonomic resolution with minimal starting material (King and others, 2008; McClenaghan and others, 2015; Iwanowicz and others, 2016; Aguilar and others, 2017). DNA barcoding is a common technique that has been used to determine the diets of multiple species, such as deep-water sharks (Dunn and others, 2010), Micropterus salmoides (largemouth bass; Jo and others, 2014), and blue catfish (Aguilar and others, 2017). Although cytochrome c oxidase 1 (COX1) is often used to speciate fishes, there are several markers available for DNA metabarcoding, including but not limited to mt $16 \mathrm{~S}$, mt18S, maturase K (matK), and ribulose biphosphate carboxylase large (rbcL) (Weigt and others, 2012). Species identifications are determined by comparison with reference sequences, which are sequences stored in databases such as GenBank (maintained by the National Center for Biotechnology Information [NCBI]) and using a sequence alignment tool such as BLAST (Basic Local Alignment Sequence Tool) (Altschul and others, 1990). This strategy allows for high taxonomic resolution from minimal starting material; however, it is expensive, and time consuming to clone and sequence many independent DNA fragments using traditional means (Iwanowicz and others, 2016). The development of next-generation sequencing increases speed and accuracy of genetic dietary analysis and may be particularly useful in relatively complex mixtures such as feces (Iwanowicz and others, 2016).

This report describes a multi-locus metabarcoding approach for the analysis of blue catfish diet using paired-end reads (reads from two ends of the same DNA molecule) of the mitochondrial 12S (mt12S) and mitochondrial 16S (mt16S) gene regions. Potential error was assessed by analyzing mock fish samples of known composition for both gene regions. In this study, a prey list was determined for 12 blue catfish caught in Mattawoman Creek and Nanjemoy Creek in Maryland during March 2017. The development of a TaqMan ${ }^{\circledR}$ quantitative polymerase chain reaction (qPCR) assay that accurately and sensitively identified Perca flavescens (yellow perch) eggs in blue catfish stomach samples is discussed.

\section{Methods}

\section{Field Collections}

Eleven blue catfish were captured from Mattawoman Creek and one blue catfish was collected from Nanjemoy Creek (both major tributaries to the Potomac River) during March 2017 (figure 1). Fish were collected using a Smith-Root SR18 Electrofishing boat outfitted with a 9.0 GPP generator. Blue catfish were collected from shallow water $(<6$ feet) and galvanonarcosis was reached with the use of high frequency pulsed DC current. All fish were euthanized with blunt force trauma followed by cervical dislocation. Total body weight and length of the fish were recorded, and stomach samples were individually preserved in 97 percent ethanol for molecular identification (table 1). In addition to DNA from blue catfish stomach samples, DNA was obtained for seven additional fish species (table 2) for inclusion in mock samples (mt12S mock and mt16S mock) for use in determining (or confirming) species specificity of the MiSeq primers. 


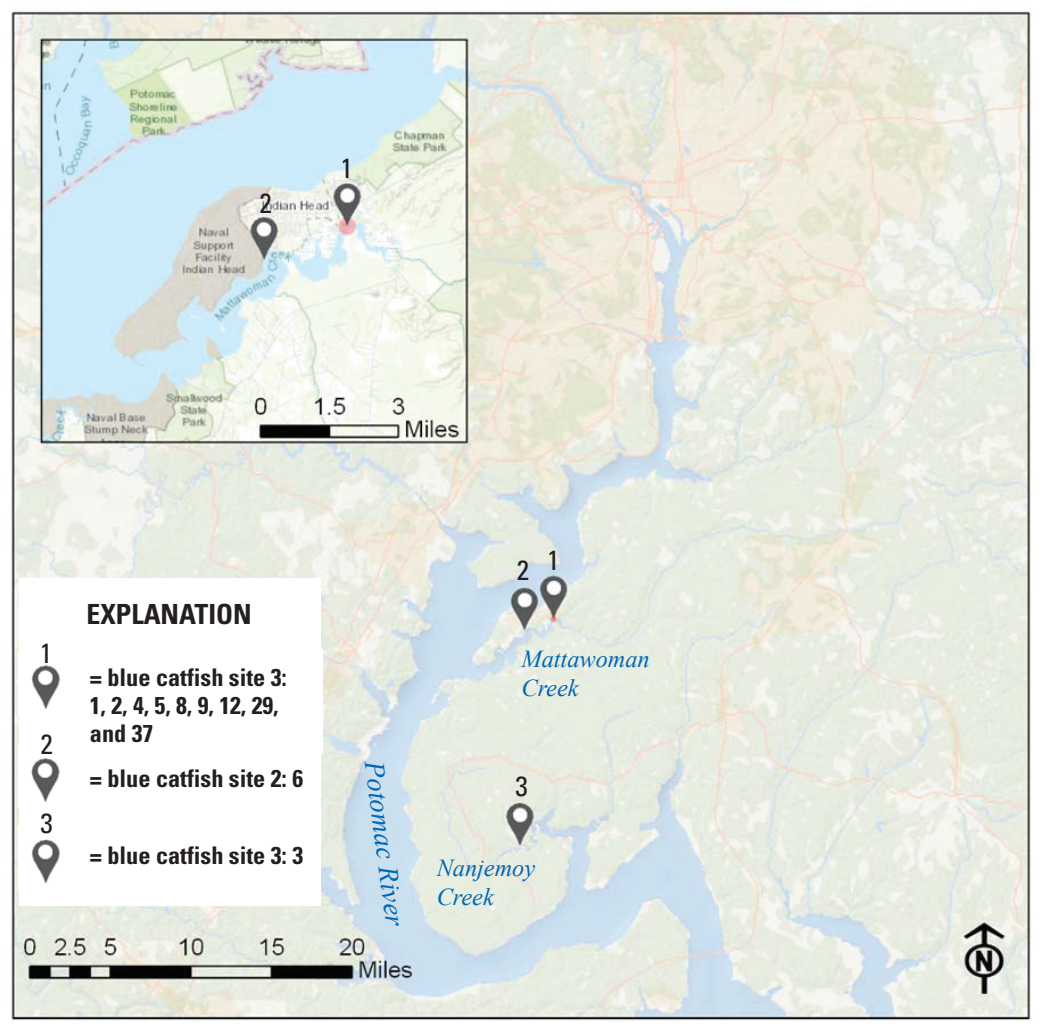

Figure 1. Three sites where Ictalurus furcatus (blue catfish) were collected from major tributaries of the Potomac River. Sites 1 and 2 were in Mattawoman Creek. Site 1 was where most fish were collected; the red dot at the bottom shows the 240-meter sampling area where the fish were collected. Site 3 was in Nanjemoy Creek. (Sources: Esri, HERE< Garmin, Intermap, increment P Corp., GEBCO, USGS, FAO, NPS, NRCAN,GeoBase, IGN, Kadaster NL, Ordinance Survey, Esri Japan, METI, Esri China (Hong Kong), swisstopo, (C) OpenStreetMap contributors, and the GIS User Community, Esri, Garmin, GEBCO, NOAA NGDC, and other contributors)

\section{DNA Extraction}

Genomic DNA (gDNA) extraction was completed following the methods of the Soil Microbe DNA Miniprep ${ }^{\mathrm{TM}}$ Kit, Zymo Research (Irvine, California). Two samples containing eggs were first washed in phosphate-buffered saline to minimize contamination from other stomach contents and then extracted following the same methods as the other stomach samples. All DNA was eluted in 30 microliter $(\mu \mathrm{L})$ of sterile, nuclease-free water. All samples were stored at -20 degrees Celsius $\left({ }^{\circ} \mathrm{C}\right)$ until polymerase chain reaction $(\mathrm{PCR})$ was performed.

\section{Targeted Amplification of Mitochondrial Regions}

The mt12S and mt16S ribosomal RNA (rRNA) gene regions were targeted owing to their common use in species identification in fishes and other vertebrates because of the highly conserved regions (Pascoal and others, 2008; Gharrett and others, 2001; Bock and others, 2016; Yang and others, 2014). The primers used for the mt $12 \mathrm{~S}$ rRNA gene region, which are described by Melton and Holland (2007), produced an approximately 250-base-pair (bp) amplicon. The primers used to analyze the mt16S rRNA gene region are described by Deagle and others (2007); these primers produce an approximately 270-bp amplicon. Amplicons for both primer sets were developed in two steps. Target DNA was first amplified using primers (either mt12S or mt16S) to generate a higher concentration of input template for the library. Then fusion primers were developed that included Illumina "overhang" sequence adapters (70 bp) attached to the original primers for a second round of PCR and library construction. The primers used for the mt12S gene region were 12SF/12SR (Melton and Holland, 2007): 12SF (5' - ACT GGG ATT AGA TAC CCC ACT ATG - 3') (A, adenine; C, cytosine; G, guanine; $\mathrm{T}$, thymine) and 12SR (5' - ATC GAT TAT AGA ACA GGC TCC TC -3 '). The primers used for the mt16S gene region were 16S1F/16S1R (Deagle and others, 2007): 16S1F (5' GAC GAK AAG ACC CTA - 3') and 16S1R (5' - CGC TGT TAT CCC TAD RGT AAC T - 3'). The initial thermocycling conditions for the primary PCR using standard primers consisted of an initial denaturation step of $94^{\circ} \mathrm{C}$ for 10 minutes, followed by 35 cycles of 45 seconds at $94^{\circ} \mathrm{C}, 45$ seconds at $53{ }^{\circ} \mathrm{C}(\mathrm{mt} 12 \mathrm{~S}) / 54{ }^{\circ} \mathrm{C}(\mathrm{mt} 16 \mathrm{~S})$, and 1.5 minutes at $72{ }^{\circ} \mathrm{C}$; the final extension was $72{ }^{\circ} \mathrm{C}$ for 7 minutes. An appropriately sized amplification product was confirmed for each reaction by electrophoresis of $5 \mu \mathrm{L}$ of the reaction product through a 1.5 percent Agarose LE gel (Phenix Research, Chandler, 
Table 1. Length, weight, and collection date for 12 Ictalurus furcatus (blue catfish) collected from the site at either Mattawoman Creek or Nanjemoy Creek in Maryland.

[mm, millimeter; g, gram]

\begin{tabular}{ccccc}
\hline Fish number & Length $(\mathbf{m m})$ & Weight $(\mathbf{g})$ & Date collected & Site number, creek name \\
\hline 1 & 703 & 4,632 & $3 / 30 / 2017$ & 1 , Mattawoman Creek \\
2 & 651 & 2,965 & $3 / 30 / 2017$ & 1 , Mattawoman Creek \\
3 & 755 & 5,710 & $3 / 13 / 2017$ & 3 , Nanjemoy Creek \\
4 & 695 & 3,430 & $3 / 30 / 2017$ & 1 , Mattawoman Creek \\
5 & 680 & 3,784 & $3 / 30 / 2017$ & 1 , Mattawoman Creek \\
6 & 576 & 2,091 & $3 / 9 / 2017$ & 2 , Mattawoman Creek \\
7 & 754 & 5,627 & $3 / 30 / 2017$ & 1 , Mattawoman Creek \\
8 & 846 & 7,627 & $3 / 30 / 2017$ & 1 , Mattawoman Creek \\
9 & 632 & 2,944 & $3 / 30 / 2017$ & 1 , Mattawoman Creek \\
12 & 587 & 2,149 & $3 / 30 / 2017$ & 1 , Mattawoman Creek \\
29 & 520 & 1,456 & $3 / 30 / 2017$ & 1 , Mattawoman Creek \\
37 & 420 & 549 & $3 / 30 / 2017$ & 1 , Mattawoman Creek \\
\hline
\end{tabular}

Table 2. Data on seven field-collected fish species archived at the laboratory and used for the mock library. DNA was extracted, and sequences were obtained. All samples were originally keyed to genus or species on the basis of morphological characteristics.

\begin{tabular}{llll}
\hline \multicolumn{1}{c}{ Family } & \multicolumn{1}{c}{ Genus species } & $\begin{array}{c}\text { GenBank accession number } \\
\text { mt12S }\end{array}$ & $\begin{array}{c}\text { GenBank accession number } \\
\text { mt16S }\end{array}$ \\
\hline Percidae & Percaflavescens & NC019572 & AY520099 \\
Centrarchidae & Lepomis macrochirus & MF621713 & JX536256 \\
Salmonidae & Coregonus hoyi & KT375339 & MK291229 \\
Cyprinidae & Semotilus atromaculatus & AF023199 & AP012107 \\
Cyprinidae & Macrhybopsis hyostoma & NC030610 & NC030610 \\
Cyprinidae & Hypophthalmichthys molitrix & MF180230 & MF180232 \\
Channidae & Channa argus & KC823605 & KT358472 \\
\hline
\end{tabular}

North Carolina) at 100 volts for 45 minutes. PCR products were cleaned with the PCR Purification Kit (Qiagen, Valencia, Calif.) and quantified using the Qubit dsDNA HS Assay Kit (ThermoFisher Scientific, Grand Island, New York). Samples were diluted in 10 millimolar Tris buffer ( $\mathrm{pH} 8.5$ ) to a final concentration of 5 nanograms per microliter. This analysis was also performed on the fish eggs found in two of the samples. Because the eggs had been ingested, along with multiple fish species, unambiguous Sanger sequencing was not possible.

\section{Generation of Mock Library Samples}

To better understand sources of error or bias in taxonomic assignment, we created two mock fish DNA assemblages by mixing purified DNA sequences from known fish species at defined concentrations (table 2). For each fish, 25 milligrams ( $\mathrm{mg}$ ) of fish tissue was extracted using the DNeasy blood and tissue kit (Qiagen, Valencia, Calif.), following the manufacturer's protocol. The mt12S and mt16S 
sequence was then amplified using the same targeted amplification of mitochondrial region as described in the previous section under targeted amplification of mitochondrial regions. Because an earlier MiSeq run had identified 7-8 fish species in the stomachs of blue catfish at a given time, a total of 7 PCR products were mixed to form 2 mock libraries (table 2). In both the mt12S mock library and the mt16S mock library, all seven PCR products were mixed in equal concentrations (mass/volume).

To confirm the identities of fishes used in these mock libraries, the mt16S amplicon was Sanger-sequenced from both ends on an ABI3130xl sequencer using Big Dye Terminator Cycle Sequencing chemistry (Applied Biosystems, Foster City, Calif.). Forward and reverse sequences were overlapped and manually edited with Geneious v10.0 (Gene Codes Corporation, Ann Arbor, Michigan).

\section{Sequencing Library Preparation and Quality Assessment}

Next-generation sequencing was performed on the Illumina MiSeq platform to observe species-specific sequences and determine the diet of the blue catfish using mt12S and mt16S primers modified with the sequencing adaptors specified in the Illumina 16S Metagenomic Sequencing Library Preparation protocol (CT \#: 15044223 Rev. B; https:// support.illumina.com/documents/documentation/chemistry_documentation/16s/16s-metagenomic-library-prep-guide15044223-b.pdf). Amplicon libraries were prepared following the same manufacturer's protocol. These adapters allowed us to pool samples from multiple catfish, sequence them cost effectively, and later sort the data bioinformatically using the Illumina Nextera XT multiplex library indices; read (nucleotide sequence) pairs are automatically assigned to samples based on these index reads by the MiSeq software. DNA read size spectra were determined with the Agilent 2100 Bioanalyzer using the Agilent DNA 1000 Kit (Santa Clara, Calif.). Libraries were quantified with the Qubit dsDNA HS Assay Kit (ThermoFisher Scientific, Grand Island, N.Y.) and normalized to 4 nanomolar (nM) using 10 millimolar (mM) Tris (hydroxymethyl) aminomethane buffer $\mathrm{pH}$ 8.5. A final concentration of 10 picomolar library with a 15 -percent PhiX control spike was created with the combined pool of all indexed libraries. All bioinformatic operations were completed on CLC Genomic Workbench v10 (Qiagen, Valencia, Calif.).

\section{Read Filtering, Trimming, and RNAseq Metabarcoding Assembly}

The mt12S and mt16S libraries were analyzed similarly but separately. In general, machine-processed FASTQ files were imported into CLC Genomics v10 (Qiagen Bioinformatics, Redwood City, Calif.) for initial filtering of exogenous sequence adaptors and poor-quality base calls. Adaptors were matched by scanning for regions of similarity to the full-length adaptor reference using a $+2 /-3$ scoring scheme for a match/ mismatch and a minimum quality score of 10 . Degenerate positions in the primer sequences were accommodated by providing multiple explicit variants as search motifs. A maximum error probability of 0.01 was allowed, and a minimum read length of 150 bases was required after all trimming steps. Machine-processed sequencing output was deposited under BioProject PRJNA509916, SRA accession SUB4912843 for both $\mathrm{mt} 12 \mathrm{~S}$ reads and $\mathrm{mt} 16 \mathrm{~S}$ reads. The trimmed overlapping paired-end reads were assembled using the CLC RNAseq Analyses assembly module with a minimum score of 10 , a mismatch cost of 2 , and an insertion cost of 3 . To ensure that all mock fish were identified, length fraction and similarity fraction were altered between the mt12S and mt16S libraries. For mt12S analyses, length fraction and similarity fraction were conservatively set at 0.98 . However, read efficiency was lower with the mt16S primers, and therefore less-conservative analyses were set at 0.90 for length fraction and 0.97 for similarity fraction. Reads were annotated using a reference library that contained one reference sequence for each species included.

\section{Reference Database and Taxonomic Analysis}

We developed separate $\mathrm{mt} 12 \mathrm{~S}$ and $\mathrm{mt} 16 \mathrm{~S}$ reference databases for analysis. First mt12S mock and mt16S mock were compared against either the $\mathrm{mt} 12 \mathrm{~S} / \mathrm{mt} 16 \mathrm{~S}$ (respectively) sequences generated with Sanger sequencing from our input fish material or those from GenBank. If longer sequences were available in GenBank, they were used because a shorter read can introduce a bias to the read score (Iwanowicz and others, 2016). A reference database was compiled that represented 203 fish and amphibian species commonly found in Mattawoman Creek and 12 common invertebrates that previously had been identified microscopically in the stomachs of blue catfish collected in Virginia and Maryland (Appendix 1).

All mt12S teleost sequences were downloaded on May 2, 2018, whereas all mt16S teleost sequences were downloaded on June 6, 2017, from the NCBI archive. This mt16S database was modified by removing all duplicates and sequences less than $150 \mathrm{bp}$ in length, resulting in 219 sequences. Eleven species were present in the study area (fig. 1) that could not be included within the mt12S database because they were not found in GenBank. Those species included Enneacanthus chaetodon (blackbanded sunfish), Enneacanthus gloriosus (bluespotted sunfish), Hybognathus hankinsoni (brassy minnow), Hiodon tergisus (mooneye), Lampetra planeri (brook lamprey), Acantharchus pomotis (mud sunfish), Lepomis microlophus (redear sunfish), Etheostoma maculatum (spotted darter), Etheostoma fusiforme (swamp darter), and Pomoxis annularis (white crappie). Counts of reads assigned to taxa were normalized as counts per million mapped reads. 


\section{Primers and Real-Time PCR (Control Gene qPCR)}

During necropsy, two fish stomachs were observed to contain primarily eggs of one or more unknown fish species. Preliminary DNA sequencing data identified the eggs as yellow perch. Since yellow perch have been managed extensively in the Chesapeake Bay (Fisheries Service Yellow PerchWorkgroup, 2002), we developed a faster, more economical method for egg identification by developing yellow perch primers and a probe for a TaqMan ${ }^{\circledR}$ qPCR assay. We began by developing two sets of yellow perch specific primers and a TaqMan probe. Primer set 1 consisted of YP154Fwd (5' - ATA AGG TTG AAC ATT TCC TCT GCC T - 3') and YP154Rev (5' - AAA AAC GTA ATA AAT CCC AGA GGG $\left.G-3^{\prime}\right)$, whereas primer set 2 consisted of YP195F (5' - CAT TTC CTC TGC CTG CAA GAT ATA G - 3') and YP195Rev (5' - CAG GAG TGT TAA CTA TCT CAG GAG T - 3'). Primer set 1 was developed to detect a 154-bp amplicon in the control region of yellow perch mitochondrial DNA (mtDNA), whereas primer set 2 detected a 195-bp amplicon in the mitochondrial control region. The yellow perch specific 6-FAM/ Zen-labeled Prime Time probe (IDTdna, Coralville, Iowa) YP Zen $\left(5{ }^{\prime}\right.$ - 6FAM/TGC TCT TGA/ZEN/TAT CCT AAG ATG TGG TTC/31ABkFQ/ - 3') and the primers based on the mitochondrial control region of yellow perch were developed using PRIMER QUEST (IDTdna, Coralville, Iowa). The specificity of primers and probes were checked with BLASTn (Basic Local Alignment Sequence Tool for nucleotides) analysis against the NCBI database to ensure that amplification of genes from other organisms or species was unlikely.

The yellow perch qPCR assay was optimized as a TaqMan ${ }^{\circledR}$ assay. Primer and probe sets were optimized on the basis of the checkerboard system. All primer optimization assays were performed on the $\mathrm{ABI}$ viiA ${ }^{\mathrm{TM}} 7 \mathrm{qPCR}$ system using a $20 \mu \mathrm{L}$ reaction containing $1 \mu \mathrm{L}$ DNA template, $1 \mathrm{X}$ Life Technologies TaqMan ${ }^{\circledR}$ Environmental Master Mix 2.0 (Applied Biosystems ${ }^{\circledR}$, Carlsbad, Calif.), primer set 1 or 2, and 0.25 micromolar $(\mu \mathrm{M})$ of the probe. Amplification conditions for the optimization assay consisted of heating at $50{ }^{\circ} \mathrm{C}$ for 2 minutes, followed by 40 cycles of $95^{\circ} \mathrm{C}$ for 15 seconds and an annealing/extension cycle of $60^{\circ} \mathrm{C}$ for 1 minute. The probe concentrations were optimized with the previously determined optimal primer concentrations and were run with four replicates at each $50 \mathrm{nM}$ interval from 50 to $250 \mathrm{nM}$. Thermocycling conditions for probe optimization were the same as the primer optimization described above. Optimal probe concentration was determined by choosing the minimum probe concentration that yielded the minimum cycle threshold. The specificity of the assay was evaluated in triplicate by assaying genomic DNA extracts of target positive controls, a wide range of sample collection negative controls (table 3 ), environmental positive controls, and a non-template control. Standards were designed to determine copy number. Dilutions of genomic DNA were used to determine the number of copies of the yellow perch mitochondrial control region sequence in all DNA samples by comparison of the qPCR response of fish
Table 3. Fish species whose genomic DNA was used to verify the specificity of the real-time polymerase chain reaction for Perca flavescens (yellow perch).

\begin{tabular}{ll}
\hline \multicolumn{1}{c}{ Species common name } & \multicolumn{1}{c}{ Order } \\
\hline Yellow perch & Perciformes \\
White sturgeon & Acipenseriformes \\
Bloater & Salmoniformes \\
\hline Blacknose dace & Cypriniformes \\
\hline Creek chub & Cypriniformes \\
\hline Atlantic salmon & Salmoniforrmes \\
\hline Silver carp & Cypriniformes \\
\hline Shoal chub & Cypriniformes \\
\hline Channel catfish & Siluriformes \\
\hline Northern snakehead & Perciformes \\
\hline
\end{tabular}

DNA samples with those of a standard dilution series $\left(10^{1}\right.$ to $10^{8}$ copies $/ \mu \mathrm{L}$ ). Calculations of standard measures of real-time analysis quality were calculated using $\mathrm{ABI}$ vii $\mathrm{A}^{\mathrm{TM}} 7$ version 1.2.1 (Life Technologies, Carlsbad, Calif.) and included determination of linear regression coefficient $\left(\mathrm{r}^{2}\right)$, slope, and reaction efficiency calculations. Samples containing one or more copies per microliter were scored as positive.

\section{Results}

\section{Sequencing Output}

We developed DNA metabarcoding methods to quantify the species composition of stomach contents of fish. We demonstrated the methods using the diet of invasive blue catfish collected from two rivers in Maryland. Total samples in the analysis consisted of 1 mock sample and the stomach samples from 12 blue catfish, which were sequenced to target the $\mathrm{mt} 12 \mathrm{~S}$ and $\mathrm{mt} 16 \mathrm{~S}$ gene regions. The total read output for these samples with the $\mathrm{mt} 12 \mathrm{~S}$ gene region was $15,473,679$ million read pairs. The total read output for these samples with the mt12S mock library was $1,950,848$ million read pairs. The total read output for these samples with mt16S was $1,395,480$ million read pairs. The total read output for these samples with the mt16S mock library was 953,640 read pairs. Initial trimming with the $\mathrm{mt} 12 \mathrm{~S}$ target region resulted in a mean read length of 151 bases. Initial trimming with the mt16S target region resulted in a mean read length of approximately 234 bases for each primer pair. 


\section{Mock Stomach Samples}

A total of $732,634 \mathrm{mt} 12 \mathrm{~S}$ and $158,034 \mathrm{mt} 16 \mathrm{~S}$ reads from the mock libraries were categorized by matching sequences to those included in the respective databases. All fish species in the mt12S and mt16S mock libraries were detected; however, we had to take a less conservative approach with the mt16S libraries by utilizing only 0.90 length fraction and 0.97 similarity fraction, instead of 0.98 for both as for the mt12S library (table 4).

In the mock samples, the mt16S primers had lower efficiency in reading sequences from Semotilus atromaculatus (creek chub), Macrhybopsis hyostoma (shoal chub), and Hypophthalmichthys molitrix (silver carp). Upon closer inspection, the primer set also had difficulties in reading sequences that matched to Ictalurids (catfish) and Micropterus sp. (such as black bass). The error was identified on the last base at the 3' end of the reverse primer. Modification of the last 3' base from an "A" to a "W" would make this primer set work more efficiently for our reference database.

\section{Blue Catfish Stomach Samples}

A total of $10,347,229 \mathrm{mt} 12 \mathrm{~S}$ (with a mean \pm standard deviation $[\mathrm{SD}]$ per sample of $795,941 \pm 255,929)$ and $855,444 \mathrm{mt} 16 \mathrm{~S}$ (with a mean $\pm \mathrm{SD}$ per sample of $77,776 \pm 23,937$ ) reads from the blue catfish stomachs were mapped to the respective database. In total, 16 species were assigned reads (fig. $2 A$ ) with the $\mathrm{mt} 12 \mathrm{~S}$ libraries at proportions

Table 4. Seven fish species included in mock samples along with the percent contribution they were found in the DNA assemblage. All fish were identified to species based on morphological characteristics.

[Percentages do not sum to 100 because of rounding]

\begin{tabular}{lcc}
\hline \multicolumn{1}{c}{ Species } & $\begin{array}{c}\text { mt12S Mock } \\
\text { (percent) }\end{array}$ & $\begin{array}{c}\text { mt16S Mock } \\
\text { (percent) }\end{array}$ \\
\hline Perca flavescens & 16 & 31 \\
\hline Lepomis macrochirus & 13 & 14 \\
\hline Coregonus hoyi & 13 & 28 \\
\hline Semotilus atromaculatus & 14 & 4 \\
\hline Macrhybopsis hyostoma & 8 & 2 \\
\hline Hypophthalmichthys molitrix & 10 & 2 \\
\hline Channa argus & 25 & 20 \\
\hline
\end{tabular}

of at least 0.02 percent of the diet. When aggregated at the genus level with mt12S, 12 genera were recovered at proportions of at least 0.02 percent of diet (fig. $2 B$ ). Nine species were found in proportions greater than 1 percent of the diet: yellow perch, Cyprinus carpio (common carp), blue catfish, Ameiurus nebulosus (brown bullhead), Alosa sapidissima (American shad), Alosa pseudoharengus (alewife), Lepomis macrochirus (bluegill), Micropterus salmoides (largemouth bass) and menhaden. With the mt16S primers, 16 species from 13 different genera were assigned reads at proportions of at least 0.02 percent of the diet (fig. $3 A, B$ ); 10 species were found in proportions greater than 1 percent of the diet. These species included the Orconectes limosus (spineycheek crayfish), yellow perch, American shad, alewife, bluegill, Dorosoma cepedianum (American gizzard shad), menhaden, blue catfish, Micropterus dolomieu (smallmouth bass), and Cyprinus carpio (common carp).The efficiency of the mt16S primer set in directing amplification of some targets was much lower than that of the mt12S primer set. Even with the lower efficiency, combining the two primer sets indicates that Perca sp., Orconectes sp., Cyprinus sp., and Alosa sp. were the most abundant genera found in the blue catfish stomachs.

\section{qPCR Assay Optimization}

Primer and probe concentrations were optimized for this qPCR assay by determining the minimum concentrations necessary to give the maximum normalized reporter value $\left(\Delta R_{n}\right)$. The $\Delta R_{n}$ reliably calculates the magnitude of the specific signal generated from a given set of PCR conditions. For primer set 1 , this was a $20-\mu \mathrm{L}$ PCR reaction that was composed of $10 \mu \mathrm{L}$ of Power Sybr ${ }^{\circledR}$ Green PCR Master Mix (Applied Biosystems, Foster City, Calif.), $0.1-\mu \mathrm{L}$ forward primer at a concentration of $0.03 \mu \mathrm{M}, 1.8-\mu \mathrm{L}$ reverse primer at a concentration of $0.09 \mu \mathrm{M}, 0.5-\mu \mathrm{L}$ probe at a concentration of $250 \mathrm{nM}$, and $6.6 \mu \mathrm{L}$ of nuclease-free water. This resulted in the same $20-\mu \mathrm{L}$ reaction described in the methods, including multiple primer concentrations (table 5). Assay conditions remained the same. Non-template controls and collection negative controls did not generate a peak with primer set $1(\mathrm{YP} 154 \mathrm{~F} / \mathrm{R})$, indicating that no nonspecific binding of the primers occurred. However, with primer set 2 (YP195F/R), melt curve analyses had peaks indicating nonspecific binding of the primers occurred. In fact, primer set 2 (YP195F/R) directed nonspecific amplification of three fish species, including creek chub, shoal chub, and Salmo salar (Atlantic salmon).

The stomach samples did test positive for yellow perch. All positive control samples were sequenced successfully using Sanger cycle sequencing, confirming the species of issue is yellow perch.

Assay performance and precision were evaluated with the described standards of yellow perch. Linear correlation $\left(r^{2}>0.98\right)$ and amplification efficiency (102.5 percent) values for yellow perch demonstrate that the developed assay has good performance over the tested quantification range, with highly reproducible results (fig. 4). 

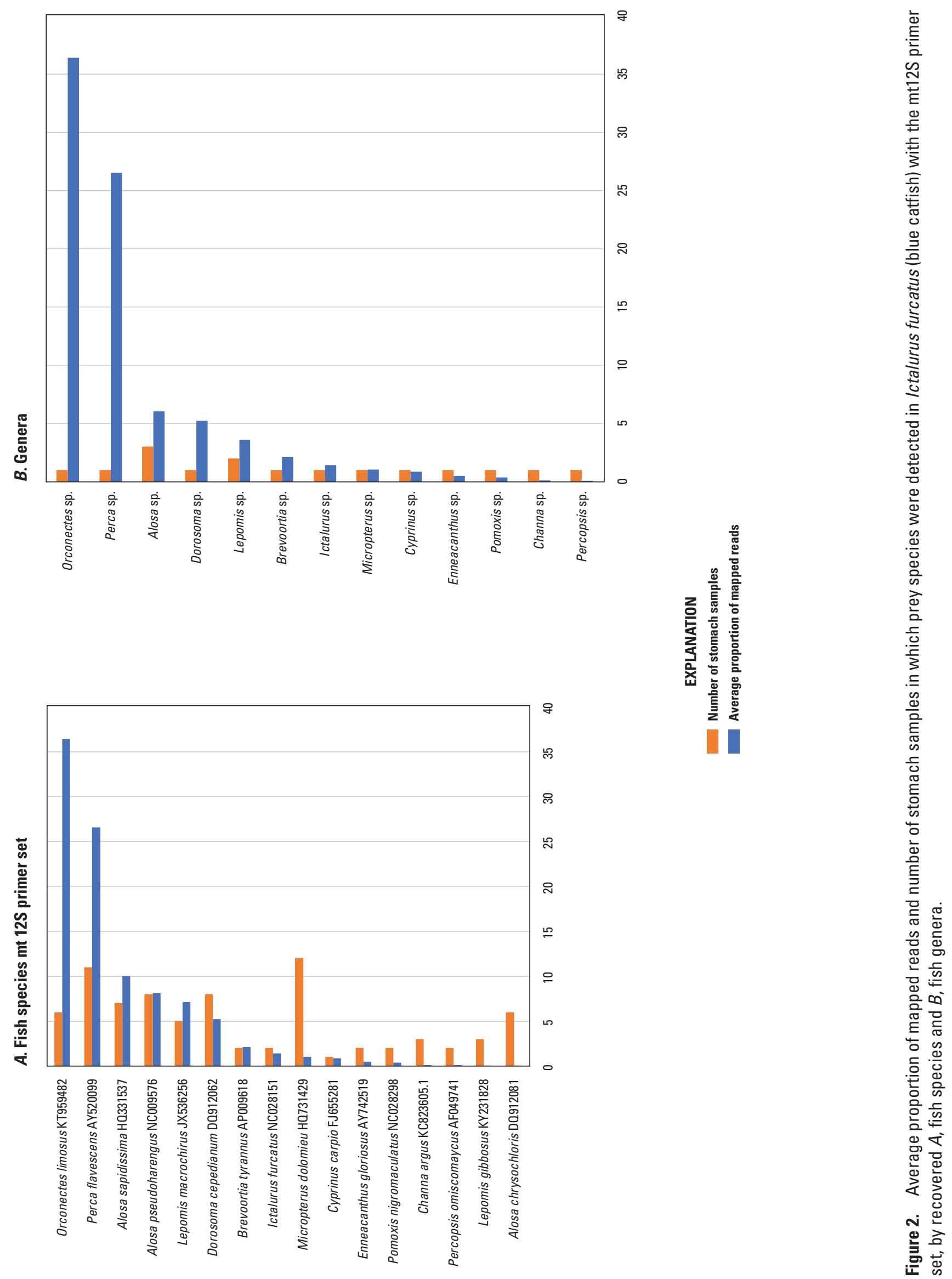

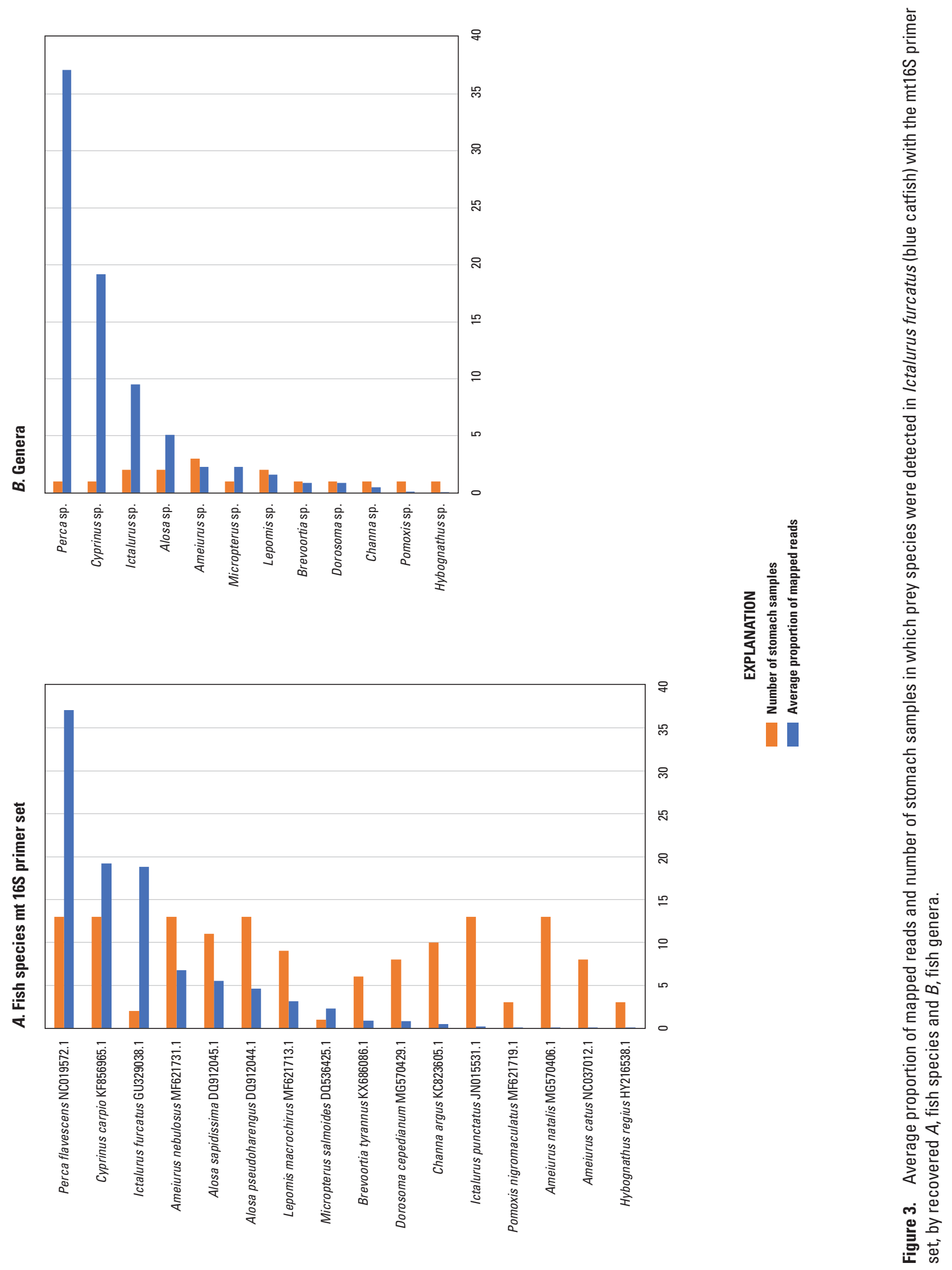
Table 5. Concentration of primers and probe used for the detection of Perca flavescens (yellow perch) in real-time polymerase chain reaction assay.

$[\mu \mathrm{M}$, micromolar $]$

\begin{tabular}{lcc}
\hline & Primer (probe) & Concentration ( $\boldsymbol{\mu M})$ \\
\hline YP154F & 0.3 \\
YP154R & 0.9 \\
YP195F & 0.3 \\
YP195R & 0.3 \\
YP Zen (probe) & 0.25 \\
\hline
\end{tabular}

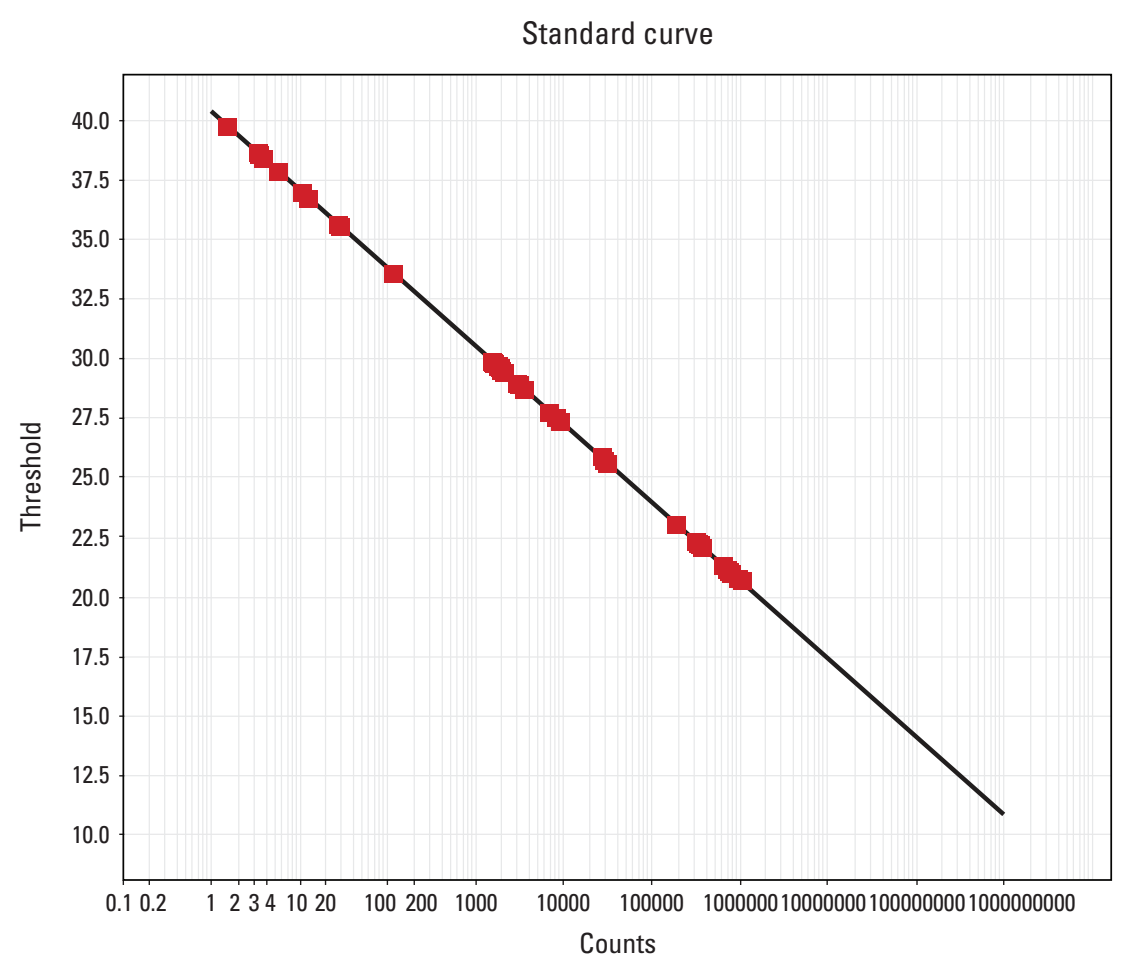

Figure 4. Threshold values in relation to counts generated by assaying fish samples with the Perca flavescens (yellow perch) real-time polymerase chain reaction assay. An overview of all assayed fish samples is presented in table 2. (Assay efficiency $=102.5, r^{2}=0.99$ and a slope of -3.262).

\section{Discussion}

This study investigated the use of mt12S and mt16S gene regions to quantify the diet of blue catfish and the use of the mitochondrial control region to identify samples as yellow perch. Owing to an accelerated evolutionary rate of animal mtDNA, significant degrees of sequence variation can be observed in closely related species (Yang and others, 2014). In animals, there are many copies of mtDNA per cell, which makes mtDNA advantageous for identification of species using degraded or low-quality DNA found in stomach samples
(Yang and others, 2014). The two ribosomal RNAs encoded in the mitochondrial genome (mt12S and mt16S) have numerous substitutions among species, which is advantageous for species identification including identification of an invertebrate species (Orconectes limosus, spinycheek crayfish). We found in this study that, in combination, sequence analysis for ribosomal RNAs yielded a comprehensive list of prey species for the 12 blue catfish captured.

Owing to differences between sites, collection dates, and molecular methods, only general comparisons can be made between this study and the study described by Aguilar and others (2017). However, many similarities can be found between 
the two studies in the diet of blue catfish. Species such as Alosa aestivalis (blueback herring), alewife, American shad, menhaden, American gizzard shad, Ameiurus catus (white bullhead), brown bullhead, Ictalurus punctatus (channel catfish), Lepomis gibbosus (pumpkinseed), bluegill, and largemouth bass were found in at least one sample in this study and the study by Aguilar and others (2017). Interestingly, only the mt16S primer set identified blueback herring, whereas only the mt12S primer set identified the bullheads, channel catfish, and largemouth bass. All other species were found using both primer sets.

Bioinformatic analysis indicated either a mismatch or errors in amplification efficiency between the mt16S primers and multiple genera within the stomach samples (Ameiurus sp., Ictalurus sp., Micropterus sp., Semotilus sp., Macrhybopsis sp., and Hypophthalmichthys sp.). However, on closer inspection using BLASTn, the mt16S primer did match well for many fish and invertebrate species (Perca sp., Channa sp., Coregonus sp., and Lepomis sp.). The results from combined $\mathrm{mt} 12 \mathrm{~S}$ and $\mathrm{mt} 16 \mathrm{~S}$ inferred diets were very similar; both primer sets identified yellow perch, common carp, blue catfish, bluegill, alewife, American shad, menhaden, American gizzard shad, and Channa argus (northern snakehead). The mt12S and mt16S primer set libraries identified alewife, yellow perch, and common carp as a main part of the diet of the 12 blue catfish collected. However, mt16S was the only primer set to identify the spinycheek crayfish.

Estimated species composition in sampled stomachs was inferred using mock genetic libraries. Mock genetic libraries were not as statistically proportional as expected. Erroneous reads are one of the challenges that constantly needs to be addressed with next-generation sequencing (Pompanon and others, 2012). For example, errors occurring in the amplicon sequence may lead to taxon misidentification (Pompanon and others, 2012). The amplification efficiency of a DNA barcoding primer is important; correct amplification allows most dietary samples analyzed to produce sequences (Pompanon and others, 2012). Although both the mt $12 \mathrm{~S}$ and $\mathrm{mt} 16 \mathrm{~S}$ primers could amplify and sequence the mock samples in isolation, amplification can be highly skewed within an environmental or multi-template PCR when some species are preferentially amplified (Pompanon and others, 2012; Deagle and others, 2007). Although changing the last base on the 3 '-end of the reverse primer from "A" to the degenerate base " $\mathrm{W}$ " may fix many of these problems, upon further investigation it was determined that there may be multiple ways to minimize errors. For example, blue catfish stomachs are large. Extraction of multiple samples from each stomach ideally would be performed to more accurately detect all species present in the stomach because the stomach contents are not evenly distributed. In addition, PCR could be conducted in triplicate for each sample to decrease the occurrence of erroneous sequencing (Pompanon and others, 2012). Finally, sequences within the $\mathrm{mt} 12 \mathrm{~S}$ and $\mathrm{mt} 16 \mathrm{~S}$ gene regions of some potential food species were not publicly available in GenBank and therefore could not be included in our reference library. Fish species commonly seen in the study area that are not in GenBank are currently being collected and sequenced to add to the reference library database. There are advantages to having a customized library database for blue catfish. Because the library database can be used for multiple States, the data can be analyzed according to the species that are available and ecologically meaningful, which allows for more accurate taxonomic assignment (Pompanon and others, 2012).

Mitochondrial DNA is commonly used to identify animals. Mitochondrial DNA (mtDNA) is found in all animal tissues; has a simple structured genome; and, because of its rapid rate of evolution that differentiates among species, it is useful for solving phylogenetic questions on different taxonomical levels (Zhang and Hewitt, 1996; Pompanon and others, 2012). Thus, mtDNA was used in our next-generation sequencing $(\mathrm{mt} 12 \mathrm{~S}$ and $\mathrm{mt} 16 \mathrm{~S})$ and in the mitochondrial control region for the identification of yellow perch.

Regarding our TaqMan ${ }^{\circledR}$ qPCR assay, primer set 2 (YP195F/R) directed nonspecific amplification of three fish species, including creek chub, shoal chub, and Atlantic salmon. Primer set 1 targeted the control region of yellow perch and successfully amplified yellow perch in positive controls and stomach samples. No negative control or non-template control was amplified during TaqMan ${ }^{\circledR}$ qPCR. Primer set 1 (YP154F/YP154R) consistently identified only yellow perch and could be used for the stomach samples. Using primers targeted for the mitochondrial control region, other work has been successful studying population-specific genetic variation within vertebrate species such as red deer, brown bear, wolf, roe deer, wild boar and Iberian lynx (Paden and others, 2009; Palomares and others, 2002). Similar protocols could be developed for any fish species that resource managers need to quickly identify. In the future, these primers will allow us to quickly and economically identify whether eggs found in the stomach contents of blue catfish (or other species) are yellow perch.

Because prey items as digesta are often highly degraded, barcoding primers might not be able to consistently amplify prey species (Deagle and others, 2006; Pompanon and others, 2012). The egg masses found in the stomachs of the two fish from this study exhibited varying degrees of degradation. Using two molecular targets (mt12S and $\mathrm{mt} 16 \mathrm{~S}$ ), we verified the identification of species from the egg mass. Sampling from the center of the egg mass improved DNA integrity relative to eggs on the outer edge, which were more degraded. Egg degradation can cause errors when using DNA barcoding. For example, Aguilar and others (2017) used DNA barcoding to identify eggs from blue catfish stomachs; however, only 50 percent of those egg samples could be identified to species. With this method, both the Illumina MiSeq platform and the TaqMan ${ }^{\circledR}$ qPCR assay produced robust data.

A more thorough study must be conducted to determine whether yellow perch eggs are commonly consumed by the blue catfish. Yellow perch inhabiting the Chesapeake Bay drainage area are unique in that they are migratory brackishwater fish that spawn in freshwater rivers (Mansueti, 1964). 
Spawning yellow perch have historically been found in all the major river systems of Maryland (Muncy, 1962). Yellow perch are important as a game fish and as prey fish for other game fish, such as Sander vitreus (walleye), smallmouth bass, and largemouth bass (Fetzer and others, 2016; Staples and others, 2017). As an integral part of the ecosystem that they inhabit, yellow perch have long been studied in top-down predator control (Thorpe, 1977; Hartman and Margraf, 1993) and bottom-up food web influences (Hayes and others, 1992; Horppila and others, 2010; Aguilar and others, 2017). A survey of anadromous fish spawning conducted by the Maryland Department of Natural Resources (MD DNR) between July 1970 and January 1975 found yellow perch in 50 percent of the sampled watercourses (O'Dell and others, 1975). Yellow perch was the second most abundant species documented, following white perch. However, by 1988 the MD DNR had to restart the hatchery program of 1890-1955 to supplement natural populations in various tributaries (Fisheries Service Yellow Perch Workgroup, 2002). By 2008, the yellow perch spawning survey did not include historical sites as a result of changes in habitat that precluded future spawning. Also, rain events (such as flooding) decimated the egg masses on the western shore of the Chesapeake Bay. The addition of large invasive fish predators can negatively affect a population of fish, such as the yellow perch, that is already subject to considerable environmental pressure from habitat degradation and changing weather patterns. Therefore, the ability to detect key prey species consumed by invasive species may prove useful in assessing the effects of these non-native predators.

Identifying potential prey species of blue catfish using both the mt12S and mt16S gene region was effective. This preliminary data indicate that nine species of fish were found using the mt $12 \mathrm{~S}$ primer set to compose more than 1 percent of the diet (yellow perch, common carp, blue catfish, brown bullhead, American shad, alewife, and bluegill). The mt16S primer set identified similar species, including spinycheek crayfish, yellow perch, American shad, alewife, bluegill, American gizzard shad, menhaden, blue catfish, smallmouth bass, and common carp, in amounts greater than or equal to 1 percent of the diet. Although the two lists are similar, the small sample size does not accurately characterize the breadth of diet of the blue catfish in the Chesapeake Bay. This study focused on methods that can be used to determine the diet of blue catfish. Further research that includes a larger sample size, increased numbers of extractions per individual, and collection of blue catfish from multiple sites and during multiple seasons would improve the knowledge of prey consumed by this predator. This method could be useful in determining prey consumed by fish species other than blue catfish.

\section{References Cited}

Aguilar, R., Ogburn, M.B., Driskell, A.C., Weigt, L.A., Groves, M.C., and Hines, A.H., 2017, Gutsy genetics: identification of digested piscine prey items in the stomach ocntents of sympatric native and introduced warmwater catfishes via DNA barcoding: Environmental Fish Biology, v. 100, no. 4, p. 325-336, accessed December 8, 2017, at https://link.springer.com/article/10.1007/s10641-0160523-8.

Altschul, S.F., Gish, W., Miller, W., Myers, E.W., and Lipman, D.J., 1990, Basic local alignment search tool: Journal of Molecular Biology, v. 215, p. 403-410, accessed February 3, 2014, at https://publications.mpi-cbg.de/ Altschul_1990_5424.pdf.

Bock, S.L., Malley, M.M., and Lema, S.C., 2016, Complete mitochondrial genomie of the speckled dace Rhinichthys osculus, a widely distributed cyrpinrid minnow of western North America: Mictochondrial DNA Part A, DNA mapping, sequencing, and analyses, v. 27, no. 6, p. 4416-4418, accessed December 8, 2017, at https://www.tandfonline. com/doi/abs/10.3109/19401736.2015.1089551.

Deagle, B., Gales, N., Evans, K., Jarman, S., Robinson, S., Trebilco, R., and Hindell, M., 2007, Studying seabird diet through genetic analysis of faeces: a case study on macaroni penguins (Eudyptes chrysolophus): PLoS One, v. 2, no. 9, p. e831, accessed June 17, 2014, at https://journals.plos.org/ plosone/article?id=10.1371/journal.pone.0000831.

Deagle, B.E., Eveson, J.P., and Jarman, S.N., 2006, Quantification of damage in DNA recovered from highly degraded samples - a case study on the faeces: Frontiers in Zoology, v. 3, p. 11, accessed December 8, 2017, at https://www.ncbi. nlm.nih.gov/pmc/articles/PMC1564134/.

Dunn, M.R., Szabo, A., McVeagh, M.S., and P.J., S., 2010, The diet of deep water sharks and the benefits of using DNA identification of prey: Deep-Sea Research Part A Oceanographic Research Papers, v. 57, p. 923-930, accessed December 8, 2017, at https://doi.org/10.1016/j. dsr.2010.02.006.

Fetzer, W.W., Jarman, S.N., Coissac, E., Pompanon, F., and Taberlet, P., 2016, Year-class variation drives interactions between warm-water predators and yellow perch: Canadian Journal of Fisheries and Aquatic Sciences, v. 73, no. 9, p. 1330-1341, accessed December 8, 2017, at http://www. nrcresearchpress.com/doi/pdf/10.1139/cjfas-2015-0275. 
Fisheries Service Yellow Perch Workgroup, 2002, Maryland tidewater yellow perch management plan: Annapolis, Md., Maryland Department of Natural Resources, 61 p., accessed January 3, 2017, at http://citeseerx.ist.psu.edu/viewdoc/dow nload do $=10.1 .1 .525 .8696 \&$ rep $=$ rep $1 \&$ type $=$ pdf.

Garman, G.C., McIninch, S., Hopler, D., and Shuart, W., 2013, Predation by introduced catfishes on selected fishery resources in Chesapeake Bay tributaries: Virginia Commonwealth University, 1-30 p., accessed December 8, 2017, at https://chesapeakebay.noaa.gov/images/stories/fisheries/ fspvcubluecatfishpredation.pdf.

Gharrett, A.J., Gray, A.K., and Heifetz, J., 2001, Identification of rockfish (Sebastes spp.) by restriction site analysis of the mitochondrial ND-3/ND-4 and 12S/16S rRNA gene regions: Fisheries Bulletin (Dublin), v. 99, p. 49-62, accessed December 8, 2017, at https://spo.nmfs.noaa.gov/ sites/default/files/5.pdf.

Graham, K., 1999, A Review of the biology and management of blue catfish: American Fisheries Society Symposium, v. 24, p. 37-49, accessed December 8, 2017, at https://www. fisheries.org/docs/pub_sympsample.pdf.

Hartman, K.J., and Margraf, F.J., 1993, Evidence of predatory control of yellow perch (Perca flavescens) recruitment in Lake Erie, U.S.A.: Journal of Fish Biology, v. 43, no. 1, p. 109-119, accessed June 15, 2015, at https://doi. org/10.1111/j.1095-8649.1993.tb00414.x.

Hayes, D.B., Taylor, W.W., and Schneider, J.C., 1992, Responses of yellow perch and the benthic invertebrate community to a reduction in the abundance of white suckers: Transactions of the American Fisheries Society, v. 121, no. 1, p. 36-53, accessed June 15, 2015, at https:// afspubs.onlinelibrary.wiley.com/doi/epdf/10.1577/15488659\%281992\%29121\%3C0036\%3AROYPAT\%3E2.3.CO $\% 3 \mathrm{~B} 2$.

Horppila, J., Olin, M., Vinni, M., Estlander, S., Nurminen, L., Rask, M., Ruuhijarvi, J., and Lehtonen, H., 2010, Perch production in forest lakes: the contribution of abiotic and biotic factors: Ecology of Freshwater Fish, v. 19, no. 2, p. 257-266, accessed December 8, 2017, at https://doi. $\operatorname{org} / 10.1111 / \mathrm{j} .1600-0633.2010 .00410 . x$.

Iwanowicz, D.D., Vandergast, A.G., Cornman, R.S., Adams, C.R., Kohn, J.R., Fisher, R.N., and Brehme, C.S., 2016, Metabarcoding of Fecal Samples to Determine Herbivore Diets: A Case Study of the Endangered Pocket Mouse: PloS One, v. 11, no. 11, p. e0165366., accessed November 16, 2016, at https://doi.org/10.1371/journal.pone.0165366.
Januchowski-Hartley, S.R., Adams, V.M., and Hermoso, V., 2017, The need for spatially explicit quantification of benefits in invasive species management: Conservation Biology, v. 32, no. 2, p. 287-293, accessed December 8, 2017, at https://doi.org/10.1111/cobi.13031.

Jo, H., Gim, J.A., Jeong, K.S., Kim, H.S., and Joo, G.J., 2014, Application of DNA barcoding for identification of freshwater carnivorous fish diets: is number of prey items dependent on size class for Micropterus salmoides?: Ecology and Evolution, v. 4, p. 219-229, accessed December 8, 2017, at https://doi.org/10.1002/ece3.921.

King, R.A., Read, D.S., Traugott, M., and Symondson, W.O.C., 2008, Molecular analysis of predation: a review of best practice for DNA-based approaches: Molecular Ecology, v. 17, no. 4, p. 947-963, accessed on May 4, 2016, at https://doi.org/10.1111/j.1365-294X.2007.03613.x.

Lohr, C.A., Hone, J., Bode, M., Dickman, C.R., Wenger, A., and Pressey, R.L., 2017, Modeling dynamics of native and invasive species to guide prioritization of management actions: Ecosphere, v. 8, no. 5, p. e01822, accessed December 8, 2017, at https://doi.org/10.1002/ecs2.1822.

Mansueti, A.J., 1964, Early development of the yellow perch, Perca flavescens: Chesapeake Science, v. 5, no. 1/2, p. 46-66, accessed December 8, 2017, at http://www.jstor. org/stable/1350790.

McClenaghan, B., Gibson, J.F., Shokralla, S., and Hajibabaei, M., 2015, Discrimination of grasshopper (Orthoptera: Acrididae) diet and niche overlap using next-generation sequencing of gut contents: Ecology and Evolution, v. 5, no. 15, p. 3046-3055, accessed on December 8, 2017, at https:// doi.org/10.1002/ece3.1585.

Melton, T., and Holland, C., 2007, Routine forensic use of the mitochondrial $12 \mathrm{~S}$ ribosomal RNA gene for species identification: Journal of Forensic Sciences, v. 52, no. 6, accessed January 5, 2018, at https://doi.org/10.1111/j.15564029.2007.00553.x.

Michaeletz, P.H., and Dillard, J.G., 1999, A survey of catfish management in the United States: Fisheries, v. 24, no. 8, p. 6-11, accessed January 5, 2018, at https:// afspubs.onlinelibrary.wiley.com/doi/pdf/10.1577/15488446\%281999\%29024\%3C0006\%3AASOCMI\%3E2.0.CO $\% 3 \mathrm{~B} 2$.

Muncy, R.J., 1962, Life history of the yellow perch, Perca flavescens, in estuarine waters of the Severn River, a tributary of the Chesapeake Bay: Chesapeake Science, v. 3, no. 3, p. 143-159. 
O’Dell, J., Gabor, J., and Dintaman, R., 1975, Survey of Anadromous Fish Spawning Areas, Completion Report, Project AFC-8: Annapolis, MD, USA, Maryland Department of Natural Resources in cooperation with Ntional Marine Fisheries Service, p. 1-183., accessed June 5, 2017, at http:// aquaticcommons.org/594/1/f_1975_safsaprd.pdf.

Pađen, L., Sadarić, I., Gomerčić, T., Sindičić, M., Gomerčić, M.D., and Slavica, A., 2009, Design of species specific primers for amplification of mitochondrial DNA of croatian wild animals: Proceedings of the International Scientific Meeting of Anatomy and Physiology, Zagreb, Croatia, Medicinska naklada, Zagreb, p. 129-137.

Palomares, F., Godoy, J.A., Piriz, A., O'Briend, S.J., and Johnson, W.E., 2002, Faecal genetic analysis to determine the presence and distribution of elusive carnivores: design and feasibility for Iberian lynx: Molecular Ecology, v. 11, no. 10, p. 2171-2182.

Pascoal, A., Barros-Velazquez, J., Cepeda, A., Gallardo, J.M., and Calo-Mata, P.A., 2008, A polymerase chain reactionrestriction fragment length polymorphism method based on the analysis of a 16S rRNA/tRNA (Val) mitochondrial region for species identification of commercial penaeid shrimps (Crustacea: Decapoda: Penaeoidea) of food interest.: Electrophoresis, v. 29, p. 499-599., accessed January 6, 2016, at https://doi.org/10.1002/elps.200700406.

Perry, J., W.G., 1969, Food habits of blue and channel catfish collected from a brackish-water habitat: Progressive Fish-Culturist, v. 31, p. 47-50., accessed June 5, 2017, at https://www.tandfonline.com/doi/pdf/10.1577/15488640\%281969\%2931\%5B47\%3AFHOBAC \%5D2.0.CO\%3 B2? needAccess $=$ true.

Pimentel, D., Zuniga, R., and Morrison, D., 2005, Update on the environmental and economic costs associated with alien-invasive species in the United States: Ecological Economics, v. 52, no. 3, p. 273-288., accessed June 5, 2017, at https://doi.org/10.1016/j.ecolecon.2004.10.002.

Pompanon, F., Deagle, B.E., Symondson, W.O.C., Brown, D.S., Jarman, S.N., and Taberlet, P., 2012, Who is eating what: diet assessment using next generation sequencing: Molecular Ecology, v. 21, no. 8, p. 1931-1950., accessed March 23, 2012 at https://doi.org/10.1111/j.1365294X.2011.05403.x.

Chesapeake Bay Program, 2012, Sustainable Fisheries Goal Implementation Team (GIT 1), accessed June 5, 2018, at https://www.chesapeakebay.net/documents/final_catfish_ policy_git_1-24-12_\%28with_signatures\%29.pdf.
Sakai, A.K., Allendorf, F.W., Holt, J.S., Lodge, D.M., Molofsky, J., With, K.A., Baughman, S., Cabin, R.J., Cohen, J.E., Ellstrand, N.C., McCauley, D.E., O’Neil, P., Parker, I.M., Thompson, J.N., and Weller, S.G., 2001, The population biology of invasive species: Annual Review of Ecology and Systematics, v. 32, p. 305-332, accessed June 5, 2018 at https://www.annualreviews.org/doi/pdf/10.1146/annurev. ecolsys.32.081501.114037.

Schloesser, R.W., Fabrizio, M.C., Latour, R.J., Garman, G.C., Greenlee, B., Groves, M.C., and Gartland, J., 2011, Ecological role of blue catfish in Chesapeake Bay communities and implication for management: American Fisheries Society Symposium, v. 77, p. 369-382, accessed January 3, 2016, at https://pdfs.semanticscholar.org/ec15/8e9162cb77913c0320 ab61f59ff45b15b110.pdf.

Staples, D.F., Maki, R.P., Hirsch, W.C., Kerfoot, W.C., LeDuc, J.F., Burri, T., Moraska Lafrancois, B., and Glase, J., 2017, Decrease in young-of-the-year yellow perch growth rates following Bythotrephes longimanus invasion: Biological Invasions, v. 19, no. 7, p. 2197-2205, accessed June 5, 2018, at https://link.springer.com/content/ pdf/10.1007\%2Fs10530-017-1431-3.pdf.

Thorpe, J.E., 1977, Morphology, physiology, behavior, and ecology of Perca fluviatilis L. and P. flavescens Mitchell: Journal of the Fisheries Research Board of Canada, v. 34, p. 1504-1514.

Tuckey, T.D., and Fabrizio, M.C., 2010, Estimating relative juvenile abundance of ecologically important finfish in the Virginia portion of Chesapeake Bay: Virginia Institute of Marine Science F-104-R-14, accessed June 5, 2018, at https://www.vims.edu/research/departments/fisheries/ programs/juvenile_surveys/data_products/reports/trawlreport_2013.pdf.

Weigt, L.A., Driskell, A.C., Baldwin, C.C., and Ormos, A., 2012, DNA barcoding fishes, in Kress, W., and Erickson, D., eds., DNA Barcodes, Methods in Molecular Biology (Methods and Protocol), v. 858: Totowa, N.J., Humana Press.

Yang, L., Tan, Z., Wang, D., Xue, L., Guan, M.X., Huang, T., and Li, R., 2014, Species identification through mitochondrial rRNA genetic analysis: Scientific Reports, v. 4, article number 4089, accessed December 17, 2017, at https://doi. org/10.1038/srep04089.

Zhang, D.X., and Hewitt, G.M., 1996, Nuclear integrations: challenges for mitochondrial DNA markers: Trends in Ecology \& Evolution, v. 11, no. 6, p. 247-251, accessed May 2, 2012, at https://doi.org/10.1016/0169-5347(96)10031-8. 
Appendix 1. Species with Accession Number and Sequence

Available online as PDF file at https://doi.org/10.3133/ofr20191021. 
For additional information, contact:

Director, Leetown Science Center U.S. Geological Survey 11649 Leetown Road Kearneysville, WV 25430

Or visit our website at: https://www.usgs.gov/centers/lsc

Publishing support provided by the West Trenton Publishing Service Center 


\section{量}

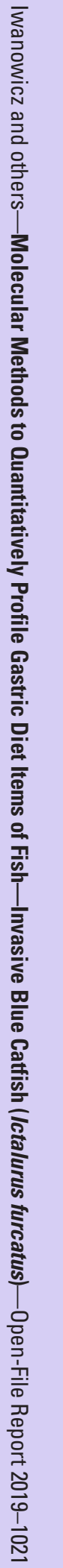

